\title{
Sustainable Business Model Innovation: Review, Analysis and Impact on Society
}

\author{
Francisco-Jose Molina-Castillo ${ }^{1, *(\mathbb{D})}$, Noemi Sinkovics ${ }^{2}(\mathbb{D})$ and Rudolf R. Sinkovics ${ }^{2,3}$ \\ 1 Facultad de Economia y Empresa, University of Murcia, 30100 Murcia, Spain \\ 2 Business School, The University of Auckland, Auckland 1010, New Zealand; \\ noemi.sinkovics@auckland.ac.nz (N.S.); rudolf.sinkovics@auckland.ac.nz (R.R.S.) \\ 3 Business School, LUT University, 53850 Lappeenranta, Finland \\ * Correspondence: fjmolina@um.es
}

check for

updates

Citation: Molina-Castillo, F.-J.; Sinkovics, N.; Sinkovics, R.R. Sustainable Business Model Innovation: Review, Analysis and Impact on Society. Sustainability 2021, 13, 8906. https://doi.org/10.3390/ su13168906

Received: 2 August 2021

Accepted: 4 August 2021

Published: 9 August 2021

Publisher's Note: MDPI stays neutral with regard to jurisdictional claims in published maps and institutional affiliations.

Copyright: (c) 2021 by the authors. Licensee MDPI, Basel, Switzerland. This article is an open access article distributed under the terms and conditions of the Creative Commons Attribution (CC BY) license (https:// creativecommons.org/licenses/by/ $4.0 /)$.

\section{Introduction}

Sustainability issues are on the rise and companies are pressured to respond [1]. Arguably, company response is a rather reactive approach and insufficient given the evidence regarding broken planetary boundaries and the immediate need for business transformation and alignment of the economic system with the planetary system [2]. For appropriately communicating social and environmental priority issues, and prompting discussions regarding natural resources and energy [3], the business model concept has become an increasingly useful tool [4,5]. Indeed, issues related to the environment, natural resources and climate change are increasingly looked at through the lens of business model innovation, adaptation and transformation processes to examine value generation at economic, social and environmental levels [6,7]. A unique feature of the business model perspective is that it allows non-science managerial audiences to appreciate discussions about planetary boundaries and system change requirements, which otherwise would be suppressed by the narrow focus on management concepts such as revenue and profit. The business model and sustainable business model innovation literatures thus offer a mechanism to reorient firm-level innovation towards sustainability, supporting conservation of natural resources [8] as well as addressing social and environmental concerns [9,10].

Societal and environmental concerns are not a recent phenomenon, but have been raised in various circles since the 1960s/70s [11,12]. For reasons related to economic prioritisation over the environment, as well as industrial-strength denial [13], real actions and sustainability innovations, however, have not entered the mainstream of the business and management literature until very recently [14]. The business model is an important conceptual advancement in this context, as it helps to balance economic with sustainability imperatives. Bocken et al. [15] investigate how businesses might create balanced social, environmental and economic value through integrating sustainability more fully into the core of their business. Joyce and Paquin [16] introduce a triple-layered business model, based on the traditional business model canvas, to address and incorporate sustainability issues. They argue for vertical and horizontal coherence of business models regarding the economic, environmental and social layers of the business model. Yang et al. [17] promote the idea of business model innovation as successful transformation towards sustainability. Furthermore, it is important to be aware that sustainable innovation has become an essential feature internationally [18]. Although the diffusion of sustainable innovation remains a challenge for many, it is indispensable in order to overcome economic barriers and gain user acceptance [9]. The rationale for becoming a sustainable company lies in the value proposition and the capacity for innovation development [17]. In fact, an increasing number of start-ups are committed to the use of innovation as a vehicle for differentiation [19], through the use of sustainable technology [20].

As a consequence of the importance of sustainability today, more and more business models are emerging with sustainable innovations and a global approach, where innovation 
and technology become key tools for their development [21,22]. Thus, there has been a shift in business models around the world, which pay close attention to sustainability as a vehicle to evolve and achieve success [23]. Business models and the notion of business model innovation (BMI) has received considerable scholarly interest in the last decade in the manufacturing and service domains [24]. Lopez-Nicolas et al. [25] found significant gender differences in business model innovation for small and medium enterprises (SMEs), and Sinkovics, Sinkovics and Yamin [4] have looked at business model reformulation at the bottom of the pyramid. The idea of transforming the logic of the organization through business model and business model innovation [26] has also been applied to the area of sustainability, although the notion of sustainable business model innovation, in this context, has sometimes been reduced to (economic) business continuity. This is why, within this special issue, we deliberately focus on "sustainability" as it relates to social and environmental issues, above and beyond economic business model innovation aspects [18]

Considering sustainability and incorporating green as a core part of a business can help many companies today to reduce costs, seize opportunities in emerging markets and gain a competitive advantage in the marketplace [9]. Some authors have suggested that sustainable business models can create social and customer value as a consequence of integrating the environment into business activities [23]. This has led more and more organisations to prioritise the diffusion of clean and renewable energy [5]. Although interest is growing, sustainable innovation in business models has not yet received the full attention it deserves [17], and there is some debate about its conceptualisation [27]. In particular, many countries still ignore the potential of sustainable innovation within the firm, so initiatives for new government regulations are rare [20].

In short, innovation in current business models is already a necessity to generate new innovative solutions in social [28], customer [29], environmental [30] and sustainable aspects [10]. For successful commercialisation of sustainable innovations, it can be crucial to have a value proposition that provides green values, a supply chain that engages suppliers to take environmental responsibility as well as initiatives that motivate customers to take consumption responsibility [18]. In addition, a financial model is needed that shows a balance between economic and ecological costs/benefits among the participants involved in the business model [5].

This special issue is concerned with the study of different aspects related to sustainable business models. We invited papers to take such questions further. How can the renewal of business models lead to improved responsiveness and firm resilience in a resource-constrained world? Is it possible to achieve systematically higher performance outcomes over traditional business models [20]? What are the promises and perils of new technologies and analytical tools such as big data and advanced ICTs [31] for business model innovation [3]? Is there any guidance for sustainability entrepreneurs [1]? How can we control and avoid the "dark sides" of such advanced technologies [32]? After several rounds of review, different works have been selected that have focused on studying the evolution of this concept, its application to different areas (waste management or the healthcare industry) and future lines of action to be taken into account for the correct implementation of sustainable business models. The following section describes the main contributions of these works and their theoretical and empirical implications.

\section{A Short Introduction to the Contributions of the Special Issue}

This first paper, "Sustainable Business Model Innovation: An Umbrella Review", conducts a deep systematic literature review around sustainable business model innovation. By using the Web of Science database, a total of 57 studies related to sustainable business models are taken into consideration. NVivo was used to dig deep regarding the different manifestations of this concept. One of the most surprising findings of this work is that none of the systematic literature reviews were published in "mainstream" business and management journals. Therefore, there is still room for further work that looks at interrelationships with other areas of business and management, such as business 
strategy. It is also interesting to see that information and communications technologies are frequently taken into consideration in the sustainable business model innovation literature.

The second paper, "Waste Management. The Disconnection between Normative and SMEs Reality", looks at norms around waste management and the reality of waste management of SMEs in Chile. Drawing on 25 in-depth interviews, the authors find (1) an absence of flexible and adequate waste norms for SMEs that consider their characteristics and practical limitations, (2) difficulties with the management and availability of sustainable raw materials and (3) a need for direct support for SMEs, reflected in tools such as subsidies, financial aid and technical assistance to approach their waste management. Additionally, the authors provide important recommendations on how to solve waste generation, focused on clear and specific norms for these SMEs.

The third article, "The Role of Public Resource Desynchronization on Business Model Sustainability in the Private Healthcare Industry", focuses on the healthcare sector. The authors offer an interesting approach to solve key questions regarding the application of sustainable business model innovation. They analyse the bed occupancy rate during the SARS-CoV-2 pandemic in Spain. Interestingly, the findings from this study reveal that the application of a myopic public health policy desynchronized the public and private healthcare sector and in turn affected business model sustainability. This "need to align" is crucial for the future of the healthcare sector. Another surprising factor is that the pandemic affected each autonomy in Spain to different degrees.

"Priorities Determining Future Directions of Sustainable Development in Business Models of the Healthcare Industry-Findings and Framework" follows on the heels of the previous article but looks at the healthcare industry from a different perspective. In particular, it analyses the relationship between private hospital communication modes and their stakeholders' needs and expectations of business models. The findings from this research provide policy and managerial recommendations that could be crucial in this sector.

The final article in the special issue is titled "Towards Sustainable Innovative Business Models", and sets out to respond to two main questions: (1) How do firms innovate their business models to deal with sustainability? (2) How do managers design the process towards more sustainable innovative business models? The authors proceed by analysing a particular Spanish company from the wine sector. An interesting finding from this work is that economic, ecological and social layers, by using a triple-layered canvas, should be considered simultaneously to design sustainable business models. Furthermore, the authors take into consideration several aspects related to family firms that should be explored in future works to increase our understanding of this topic.

Author Contributions: Conceptualization, F.-J.M.-C., N.S. and R.R.S.; investigation, F.-J.M.-C., N.S. and R.R.S.; writing-original draft preparation, F.-J.M.-C., N.S. and R.R.S.; writing-review and editing, F.-J.M.-C., N.S. and R.R.S. All authors have read and agreed to the published version of the manuscript.

Funding: This research received no external funding.

Conflicts of Interest: The authors declare no conflict of interest.

\section{References}

1. Poponi, S.; Arcese, G.; Mosconi, E.M.; Arezzo di Trifiletti, M. Entrepreneurial Drivers for the Development of the Circular Business Model: The Role of Academic Spin-Off. Sustainability 2020, 12, 423. [CrossRef]

2. Hofstetter, J.S.; De Marchi, V.; Sarkis, J.; Govindan, K.; Klassen, R.; Ometto, A.R.; Spraul, K.S.; Bocken, N.; Ashton, W.S.; Sharma, S.; et al. From Sustainable Global Value Chains to Circular Economy-Different Silos, Different Perspectives, but Many Opportunities to Build Bridges. Circ. Econ. Sustain. 2021, 1, 21-47. [CrossRef]

3. Minatogawa, V.L.F.; Franco, M.M.V.; Rampasso, I.S.; Anholon, R.; Quadros, R.; Durán, O.; Batocchio, A. Operationalizing Business Model Innovation through Big Data Analytics for Sustainable Organizations. Sustainability 2020, 12, 277. [CrossRef]

4. Sinkovics, N.; Sinkovics, R.R.; Yamin, M. The role of social value creation in business model formulation at the bottom of the pyramid-Implications for MNEs? Int. Bus. Rev. 2014, 23, 692-707. [CrossRef] 
5. Boons, F.; Lüdeke-Freund, F. Business models for sustainable innovation: State-of-the-art and steps towards a research agenda. J. Clean. Prod. 2013, 45, 9-19. [CrossRef]

6. Sinkovics, N.; Archie-Acheampong, J. The social value creation of MNEs-A literature review across multiple academic fields. Crit. Perspect. Int. Bus. 2020, 16, 7-46. [CrossRef]

7. Sinkovics, R.R.; Forsgren, M.; Sinkovics, N.; Holmström Lind, C. Social value creation in International Business-Introduction to the special issue. Crit. Perspect. Int. Bus. 2020, 16, 1-6. [CrossRef]

8. Konietzko, J.; Bocken, N.; Hultink, E.J. Circular ecosystem innovation: An initial set of principles. J. Clean. Prod. 2020, $253,119942$. [CrossRef]

9. Pieroni, M.P.; McAloone, T.C.; Pigosso, D.C.A. Business model innovation for circular economy and sustainability: A review of approaches. J. Clean. Prod. 2019, 215, 198-216. [CrossRef]

10. Aagaard, A.; Lindgren, P. The Opportunities and Challenges of Persuasive Technology in Creating Sustainable Innovation and Business Model Innovation. Wirel. Pers. Commun. 2015, 81, 1511-1529. [CrossRef]

11. Carson, R. Silent Spring, 50th ed.; Mariner Books (Houghton Mifflin): New York, NY, USA, 2002.

12. Meadows, D.H.; Meadows, D.L.; Randers, J.; Behrens, W.W.I. The Limits to Growth: A Report for the Club of Rome's Project on the Predicament of Mankind; Universe Books: New York, NY, USA, 1972.

13. Freese, B. Industrial-Strength Denial: Eight Stories of Corporations Defending the Indefensible, from the Slave Trade to Climate Change; University of California Press: Oakland, CA, USA, 2020.

14. Latapí Agudelo, M.A.; Jóhannsdóttir, L.; Davídsdóttir, B. A literature review of the history and evolution of corporate social responsibility. Int. J. Corp. Soc. Responsib. 2019, 4, 1. [CrossRef]

15. Bocken, N.; Short, S.; Rana, P.; Evans, S. A value mapping tool for sustainable business modelling. Corp. Gov. 2013, 13, 482-497. [CrossRef]

16. Joyce, A.; Paquin, R.L. The triple layered business model canvas: A tool to design more sustainable business models. J. Clean. Prod. 2016, 135, 1474-1486. [CrossRef]

17. Yang, M.; Evans, S.; Vladimirova, D.; Rana, P. Value uncaptured perspective for sustainable business model innovation. J. Clean. Prod. 2017, 140, 1794-1804. [CrossRef]

18. Bohnsack, R.; Pinkse, J.; Kolk, A. Business models for sustainable technologies: Exploring business model evolution in the case of electric vehicles. Res. Policy 2014, 43, 284-300. [CrossRef]

19. Stanko, M.A.; Molina-Castillo, F.-J.; Harmancioglu, N. It Won't Fit! For Innovative Products, Sometimes That's for the Best. J. Prod. Innov. Manag. 2015, 32, 122-137. [CrossRef]

20. Carayannis, E.G.; Grigoroudis, E.; Sindakis, S.; Walter, C. Business Model Innovation as Antecedent of Sustainable Enterprise Excellence and Resilience. J. Knowl. Econ. 2014, 5, 440-463. [CrossRef]

21. Girotra, K.; Netessine, S. Business Model Innovation for Sustainability. SSRN Electron. J. 2013. [CrossRef]

22. Trigo, A.; Varajao, J.; Barroso, J.; Soto-Acosta, P.; Molina-Castillo, F.J.; Gonzalvez-Gallego, N. Enterprise Information Systems Adoption in Iberian Large Companies: Motivations and Trends. In Managing Adaptability, Intervention, and People in Enterprise Information Systems; IGI Global: Hershey, PA, USA, 2011; pp. 204-228. [CrossRef]

23. Schaltegger, S.; Lüdeke-Freund, F.; Hansen, E.G. Business Models for Sustainability. Organ. Environ. 2016, 29, 264-289. [CrossRef]

24. Molina-Castillo, F.-J.; Meroño-Cerdan, A.-L.; López-Nicolás, C. Impact of business model objectives on marketing innovation activities. Eur. J. Innov. Manag. 2019, 23, 177-195. [CrossRef]

25. Lopez-Nicolas, C.; Nikou, S.; Molina-Castillo, F.-J.; Bouwman, H. Gender differences and business model experimentation in European SMEs. J. Bus. Ind. Mark. 2020, 35, 1205-1219. [CrossRef]

26. Markides, C.; Sosa, L. Pioneering and First Mover Advantages: The Importance of Business Models. Long Range Plan. 2013, 46, 325-334. [CrossRef]

27. Stubbs, W.; Cocklin, C. Conceptualizing a "Sustainability business model". Organ. Environ. 2008, 21, 103-127. [CrossRef]

28. Molina-Castillo, F.-J.; Lopez-Nicolas, C.; Soto-Acosta, P. Interaction effects of media and message on perceived complexity, risk and trust of innovative products. Eur. Manag. J. 2012, 30, 577-587. [CrossRef]

29. Stanko, M.A.; Bohlmann, J.D.; Molina-Castillo, F.-J. Demand-side inertia factors and their benefits for innovativeness. J. Acad. Mark. Sci. 2013, 41, 649-668. [CrossRef]

30. Taherdangkoo, M.; Mona, B.; Ghasemi, K. The role of industries' environmental reputation and competitive intensity on sustainability marketing strategy. Span. J. Mark. ESIC 2019, 23, 3-24. [CrossRef]

31. Rodriguez, R.; Molina-Castillo, F.-J.; Svensson, G. Enterprise resource planning and business model innovation: Process, evolution and outcome. Eur. J. Innov. Manag. 2020, 23, 728-752. [CrossRef]

32. Sinkovics, R.; Sinkovics, N. The internet and international marketing-From trigger technology to platforms and new markets. Int. Mark. Rev. 2020, 37, 437-446. [CrossRef] 